Article

\title{
Effects of Natural Hail on the Growth, Physiological Characteristics, Yield, and Quality of Vitis vinifera L. cv. Thompson Seedless under Mediterranean Growing Conditions
}

\author{
Despoina G. Petoumenou ${ }^{1, *}$, Katerina Biniari ${ }^{2}$, Efstratios Xyrafis ${ }^{1}$, Dimitrios Mavronasios ${ }^{2}$, \\ Ioannis Daskalakis ${ }^{2}$ and Alberto Palliotti ${ }^{3}$ \\ 1 Department of Agriculture Crop Production and Rural Environment, Laboratory of Viticulture, \\ University of Thessaly, 38446 Volos, Greece; xyrafis@agr.uth.gr \\ 2 Department of Crop Science, Laboratory of Viticulture, Agricultural University of Athens, Iera Odos, 75, \\ 11855 Athens, Greece; kbiniari@aua.gr (K.B.); dimmavronasios@gmail.com (D.M.); \\ john-daskalakis@hotmail.com (I.D.) \\ 3 Dipartimento di Scienze Agrarie e Ambientali, Università di Perugia, Borgo XX Giugno 74, \\ 06128 Perugia, Italy; alberto.palliotti@unipg.it \\ * Correspondence: petoumenou@uth.gr; Tel.: +30-2421-093-180
}

Received: 25 March 2019; Accepted: 15 April 2019; Published: 17 April 2019

\begin{abstract}
Hailstorms are typically localized events, and very little is known about their effect on crops. The objective of this study was to examine the physiological and vine performance responses to natural hail, registered four weeks after full bloom, of field-grown Thompson seedless (Vitis vinifera L.) grapevines, one of the most important table grape varieties cultivated in Greece and especially in the Corinthian region in northeastern Peloponnese. Leaf gas exchange, vegetative growth, vine balance indices, cane wood reserves, yield components, and fruit chemical composition were recorded from hail-damaged vines and compared with control vines. Visibly, the extent of the hailstorm damage was great enough to injure or remove leaves as well as cause partial stem bruising and partial injury or total cracking of berries. Our results indicated that natural hail did not affect leaf photosynthesis, berry weight, total acidity, and cane wood reserves but significantly reduced the total leaf area, yield, and the total phenolics of berries at harvest. At the same time, hail-damaged vines increased the leaf area of lateral canes and presented a higher total soluble solid (TSS) accumulation, while no effect on the next year's fertility was registered. The present work is the first attempt to enhance our understanding of the vegetative yield, berry quality, and physiological responses of grapevines to natural hail, which is an extreme and complex natural phenomenon that is likely to increase due to climate change.
\end{abstract}

Keywords: leaf area; table grapes; photosynthesis; berry composition; phenolics; natural hail

\section{Introduction}

The Thompson seedless table grape cultivar (Vitis vinifera L.), introduced in Greece in 1838 [1], is by far one of the most important crops in the region of Corinthia, in northeastern Peloponnese (Greece). Owing to the optimal characteristics of the soil and environmental conditions from the climate of the Gulf of Corinth, this cultivar rapidly reached high-level quality standards. From there, Thompson seedless cultivation expanded to several other regions of Greece. Thus, it is now the most cultivated seedless cultivar for fresh consumption and second only to Black Corinth for raisin production in Greece [2]. 
High-impact weather events in Greece, including hail, are well documented [3,4] and result in significant subsequent socioeconomic impacts $[4,5]$. Nevertheless, very little is known about the effects of hailstorms on crops. Indeed, numerous studies have been conducted on the effects of simulated hail damage on different crops [6-9], but the effects of natural hail have scarcely been investigated [10,11].

There are significant variations in terms of crop damage due to different factors concerning both hail and crops. Therefore, the amount of damage can vary in terms of hailstone size and intensity, the kinetic energy of the hailstones [12], and the presence of wind accompanying hailfall. In addition, some crop conditions can influence the extent of the damage (i.e., the growth stage and the elasticity of the vegetation).

The cultural practices required to obtain the optimum yield and quality of the Thompson seedless cultivar have already been achieved by several studies on training system, defoliation [13], cluster thinning, girdling, the application of gibberellins, or a combination of all of these [14-16]. However, modern table grape growers are faced with front vineyard management problems that are amplified by climate change effects, such as heat waves [17], drought [18], frost [19], flooding [20], wind [21], and hailstorms. In particular, hailstorms can be very detrimental to crops and lead to the complete loss of the harvest. In Greece, during the period 1999-2011, damage costs from hail accounted for $26.2 \%$ of total insured crop losses [5]. In order to reduce these losses, anti-hail nets have been used as a protective measure for crops, but their ability to modify the tree microclimate might also alter tree growth and quality [22].

Even though several studies have been conducted on the effect of extreme weather events on grapevine growth [23,24] and physiology [24-26], as well as grape and wine quality [27-29], it is not clear yet what effects hailstorms have, directly or indirectly, on grapevine physiology and performance.

In light of this uncertainty, we studied the effects of natural hail on some important Thompson seedless grapevine leaf physiological parameters and determined its impact on vegetative growth and vine performance (yield and fruit composition).

\section{Materials and Methods}

\subsection{Plant Material and Experimental Layout}

The trial was undertaken at a commercial table grape vineyard located in Laliotis, a municipal unit of Kiato (northeastern Peloponnese, Greece, Figure 1), over the 2015 and 2016 growing seasons. The vineyard ( $38^{\circ} 01^{\prime} 10.9^{\prime \prime} \mathrm{N}, 22^{\circ} 40^{\prime} 41.4^{\prime \prime}$ E, elevation $405 \mathrm{~m}$ a.s.l., silty clay loam soil) was a 15-year-old planting of $V$. vinifera L. cv. Thompson seedless grafted onto 110R rootstock. Plant distances were $1.20 \mathrm{~m}$ within the row and $2.80 \mathrm{~m}$ between rows ( 2976 vines/ha), trained to a Y-trellis system with three to four canes/vine and three to four spurs/vine. A 20-min hailstorm took place on 18 June 2015 (the 169th day of the year, DOY), four weeks after full bloom (known as development stage EL-33 [30]); it was preceded by heavy rain $(36 \mathrm{~mm} / \mathrm{h})$ and accompanied by wind velocities up to $78 \mathrm{~km} / \mathrm{h}$ and hailstone diameters of 25-30 $\mathrm{mm}$. The hailstorm hit only one part of the vineyard, so this situation was very favorable for analyzing hailstorm effects on grapevine plants. So, two treatments were compared: control vines (ND, hail-damaged) and hail-damaged (HD) vines, the canopy of which was visibly damaged by the hailstorm. The vines were drip-irrigated at $3500-4000 \mathrm{~m}^{3} /$ ha, while fertilization, pest control, and cultural practices (berry thinning, leaf removal, shoot thinning, and shoot trimming) were conducted according to local practices. Furthermore, the following climatic data were recorded by a weather station (Wireless Vantage Pro2 ${ }^{\mathrm{TM}}$, with a $24-\mathrm{h}$ Fan Aspirated Radiation Shield, Davis Instruments, Canada USA) situated close to the trial site: monthly mean air temperature in 2015 and during 2005-2014, monthly rainfall in 2015, and average monthly rainfall during a recent decade (2005-2014). 

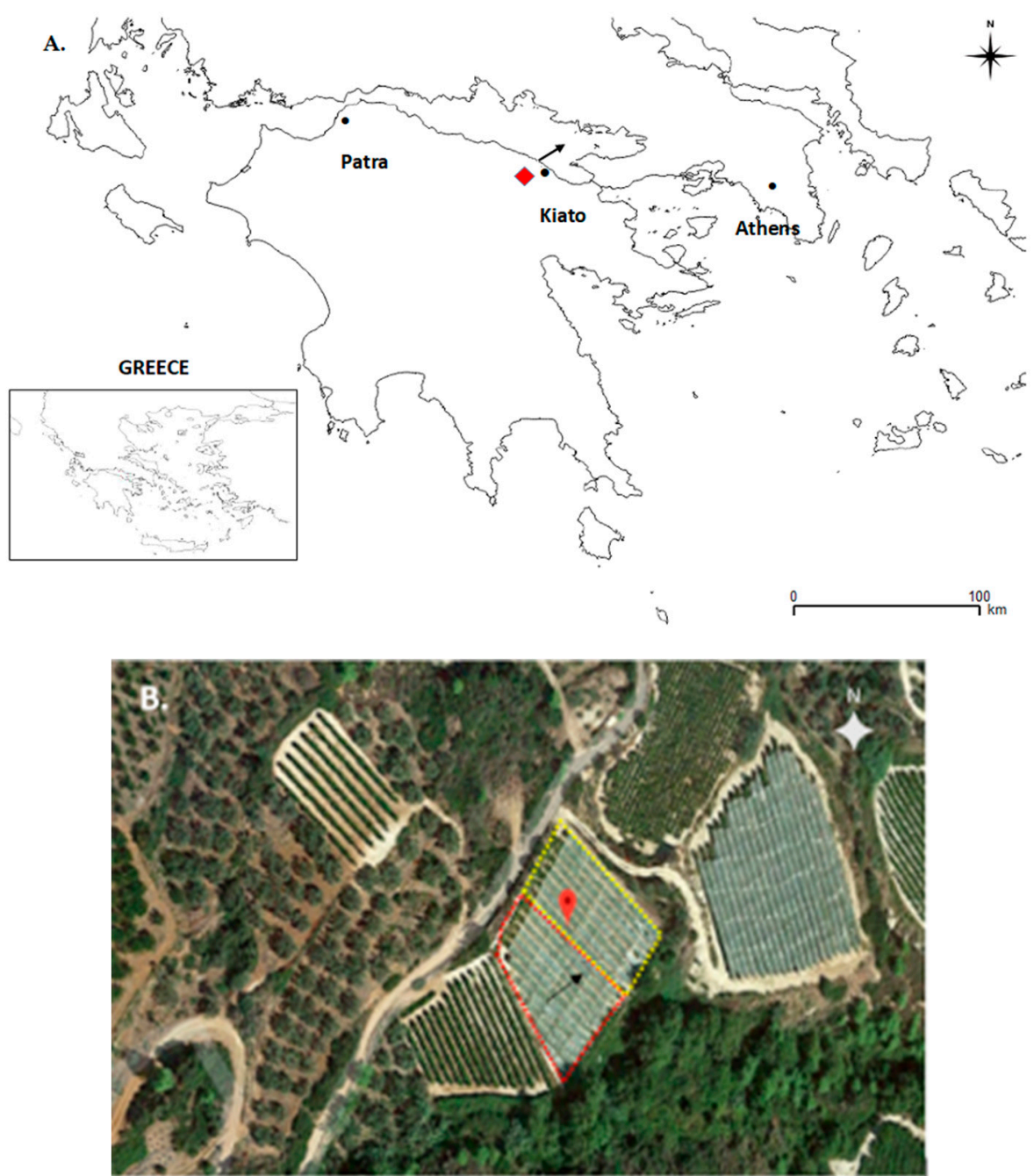

Figure 1. (A) Study area map of the Thompson seedless vineyard in the Gulf of Corinth $(>$ northeastern Peloponnese, Greece). (B) The red and yellow dotted lines indicate the approximate areas of the vineyard that were affected or unaffected by the hailstorm, respectively. Black arrowheads indicate the approximate direction of the hailstorm on 18 June 2015.

The experiment was a randomized block design with two treatments-control (ND) and HD vines-in five replications. Each plot consisted of three grapevines (experimental unit), so there were 15 grapevines in each treatment.

Immediately after the hailstorm, visual effects of falling hailstones were observed. These included:

(a) leaves still attached to grapevines with holes punched through them, creating hail injury;

(b) partial defoliation to primary and lateral shoots;

(c) partial injury or total cracking of berries;

(d) partial stem and bark bruising;

(e) primary and lateral shoots with partial hail injury on the epidermis.

All of these hail injuries were observed only on sides facing the direction of the hailstorm (i.e., to the south and east). No shoot was removed and any shoot topping was observed because the grapevines had already been trimmed by the time of the hailstorm.

No infection of pathogens to retained leaves, shoots, or bunches was observed due to the special nutrition and plant protection schedule applied before the hailstorm, immediately afterwards, and until leaf fall. 


\subsection{Leaf Gas-Exchange Measurements}

Two days after the natural hailstorm (DOY 171), the single leaf assimilation rate (Pn), stomatal conductance $\left(\mathrm{g}_{\mathrm{s}}\right)$, and leaf transpiration rate $(\mathrm{E})$ of intact and hail-damaged leaves were measured simultaneously. The readings were repeated at DOY 186, 231, 247 (harvest), and 320 (two weeks before leaf fall) with a LC Pro+ portable photosynthesis system (ADC Bioscientific Ltd., Hoddesdon, UK). One shoot per vine (five shoots per treatment) was chosen and the readings were taken at the 3rd (basal) and 10th (medial) well-exposed leaves from the base of the main shoot and at the 3rd young leaf of the lateral shoot in the morning between 10 a.m. and 12 p.m. on sunny days under saturating photosynthetic active radiation (PAR $>1500 \mu \mathrm{mol}$ photons $\mathrm{m}^{-2} \mathrm{~s}^{-1}$ ). The readings of hail-damaged leaves were taken in leaf areas immediately adjacent to the hail injury. Concurrently, on the same leaves, intrinsic water use efficiency $\left(\mathrm{WUE}_{\mathrm{i}}\right)$ was derived as the Pn-to-g $\mathrm{g}_{\mathrm{s}}$ ratio.

\subsection{Vegetative Data, Productive Traits, and Fruit Composition}

Two days after the hailstorm, the total leaf area from the primary and lateral canes and the corresponding total leaf area $\left(\mathrm{m}^{2}\right)$ from each were estimated by removing 10 canes from 10 randomly chosen vines per treatment and measuring the real leaf area (LA) with a portable leaf area meter LI-3000 (Li-Cor Biosciences, Lincoln, NE, USA); the same procedure was used at harvest in order to determine vegetative growth. Concurrently, the total number of nodes per vine, the diameter of the primary canes at the 3rd and 10th internode, and the diameter of the lateral canes at the 3rd internode were registered.

At the end of December 2015, the one-year-old pruning weight was recorded for all vines and the yield-to-pruning-weight ratio was calculated. Vine balance was also assessed by calculating the total leaf-area-to-yield ratio (vine basis) in both treatments.

At harvest, performed on 5 September 2015 (DOY 248), when the sugar accumulation on ND vines reached 20 degrees Brix $\left({ }^{\circ} \mathrm{Bx}\right)$, all experimental vines were individually hand-picked and yield per vine was measured at the same time as the total number of bunches. Thereafter, the bunches were immediately weighed, and the total number of damaged and undamaged berries per bunch was counted. The bunch length and width were also recorded. The bunch compactness index was estimated as the bunch-weight-to-(bunch length) ${ }^{2}$ ratio, according to Tello and Ibáñez [31].

Concurrently, five samples of 200 berries per treatment were randomly collected. From each sample, 175 berries were used in order to determine the following berry characteristics: berry weight, berry length and diameter (using an electronic digital caliper), and force pedicel detachment (using a digital dynamometer (PCE Italia s.r.l., Capannori, Italy)—expressed in Newton (N).

After these measurements, the same berry samples were crushed and the must was obtained in order to determine the following berry quality characteristics. Total soluble solids (TSS) were measured using a digital hand-held "pocket" refractometer PAL (Atago Co., Ltd., Tokyo, Japan) and expressed in ${ }^{\circ} \mathrm{Bx}$ at $20^{\circ} \mathrm{C}$. A digital HI-2002 Edge $\mathrm{pH}$ meter (Hanna Instruments, Rhode Island, USA) was used to measure must $\mathrm{pH}$, and values were expressed in $\mathrm{pH}$ units. Titratable acidity (TA) was determined by titration of grape juice with a $0.1 \mathrm{~N}$ sodium hydroxide $(\mathrm{NaOH})$ solution in the presence of a bromothymol blue indicator and expressed as tartaric acid percent (\%). Also, the maturity index was calculated as the ratio TSS/TA. The remaining berries ( 25 berries per treatment) were frozen at $-20^{\circ} \mathrm{C}$, and after a few days, total skin phenolic contents were determined as described by Slinkard and Singleton [32], and their concentration was expressed as milligrams per kilo of fresh berry weight $(\mathrm{mg} / \mathrm{Kg})$.

\subsection{Carbohydrate and Nitrogen Storage in Above-Ground Permanent Vine Organs}

At the end of December 2015, the soluble sugars and starch concentrations in primary canes (3rd and 10th internode) and lateral canes (3rd internode) were determined on seven replicates per treatment according to Morris (1948) [33] and Loewus (1952) [34] and expressed in $\mathrm{mg} \mathrm{g}^{-1}$ of dry weight (DW). 


\subsection{Shoot Fertility and Blind Buds}

In spring 2016, during the phenological phase of visible inflorescences, seven uniform vines per treatment were selected and the bud fertility index (number of bunches/shoot) was evaluated. At the same time, the number of blind buds per vine was determined in the same vines.

\subsection{Statistical Analysis}

All data were processed by a two-way analysis of variance using the SigmaStat software package (Systat Software, Inc. San Jose, California, USA). Treatment comparison was performed by $t$-test at $p<0.05$ and $p<0.01$. All traits are shown as mean \pm standard error.

\section{Results and Discussion}

\subsection{Meteorological Data}

The average daily temperature during vegetative and reproductive growth until harvest was always higher compared with the same period in the recent decade (2005-2014), whereas the rainfall from February to October 2015 exceeded the average monthly rainfall as compared with the period 2005-2014 (Figure 2). The amount of rainfall in June 2015 was registered in concomitance with the hailstorm and represented only $5 \%$ of the total rainfall $(692 \mathrm{~mm}$ ) of that year (Figure 2).

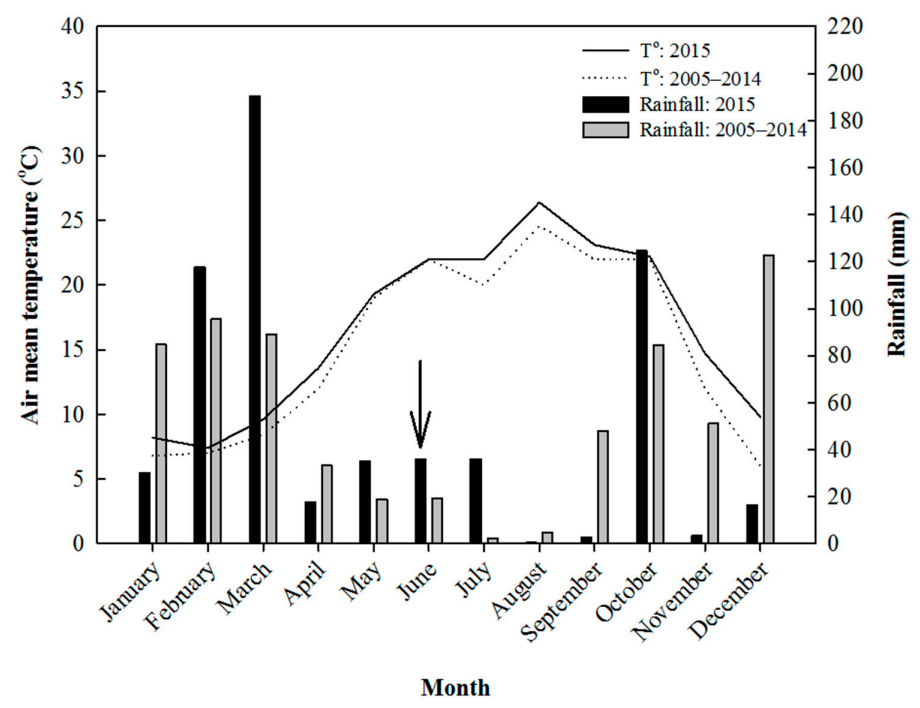

Figure 2. Seasonal trends (January-December) of monthly mean air temperature, monthly rainfall recorded in 2015, and average monthly temperature and rainfall in 2005-2014 close to the trial site. The arrow indicates the time of the hailstorm.

\subsection{Effect of Natural Hail on Vegetative Growth}

Hail impact differed strongly among the plant species and was related to their vegetative characteristics: plant height, growth form, leaf traits, and stem type [35]. For our experiment, total leaf area just after the hailstorm is shown in Table 1. The data indicate that this natural phenomenon removed 1.40 and $0.41 \mathrm{~m}^{2}$ of leaf area/vine on primary and lateral shoots of HD vines, respectively, causing a total leaf area of HD vine reduction of $1.81 \mathrm{~m}^{2} /$ vine compared with ND vines (Table 1 ). This led to a $16.4 \%$ loss of the whole leaf area of HD vines, as demonstrated by the defoliated and scarred leaves caused by the hailstones (Figure 3). Such damage has been reported in other crops [36], and hail damage can be related to the architectural features of a plant species [35].

At harvest, the shoot number was very similar for both ND and HD vines, and despite the hail injury on the phloem (Figure 4) of the primary and lateral shoots of HD vines, there was no statistically significant difference in cane diameter between the two treatments (Table 1). Nevertheless, the lateral 
shoot number for HD vines was higher (31\%) compared with ND vines and led to $8.6 \%$ more leaf area compared with the same vines just after hail (Table 1). This indicates the response of grapevines to natural hail (i.e., to stimulate the buds of primary shoots to outbreak and to develop new lateral shoots). Moreover, since no reports have been found in the scientific literature in which the effects of natural hail on grapevines were studied, it is not wrong to compare the effects of natural hail with those obtained by defoliation. In fact, the ability of vines to increase their lateral leaf area with defoliation (status derived from natural hail, in our case) is already known $[37,38]$. The total leaf area of HD vines was about $8.5 \%$ less compared with ND ones (Table 1 ) at harvest due to a lower leaf area of primary canes caused by hail damage (Table 1). These results are in accordance with other reports on crops such as maize [9].

Table 1. Vegetative growth (mean $\pm \mathrm{SE}, n=10$ ) just after hail and at harvest in non-hail-damaged (ND) and hail-damaged (HD) field-grown Thompson seedless vines.

\begin{tabular}{|c|c|c|c|}
\hline Parameters & ND & HD & Signif. $^{a}$ \\
\hline \multicolumn{4}{|l|}{ Just after hail (DOY 169) } \\
\hline Total leaf area from primary canes $\left(\mathrm{m}^{2} /\right.$ vine $)$ & $8.90 \pm 0.33$ & $7.50 \pm 0.18$ & * \\
\hline Total leaf area from lateral canes $\left(\mathrm{m}^{2} / \mathrm{vine}\right)$ & $2.11 \pm 0.12$ & $1.70 \pm 0.10$ & * \\
\hline Total leaf area $\left(\mathrm{m}^{2} /\right.$ vine $)$ & $11.01 \pm 0.28$ & $9.20 \pm 0.17$ & * \\
\hline \multicolumn{4}{|l|}{ At harvest (DOY 248) } \\
\hline Shoots/vine & $12.7 \pm 0.05$ & $13.0 \pm 0.08$ & ns \\
\hline Lateral shoots/vine & $9.43 \pm 0.04$ & $12.34 \pm 0.06$ & * \\
\hline Cane diameter at 3 rd internode (mm) & $10.37 \pm 0.29$ & $10.73 \pm 0.13$ & ns \\
\hline Cane diameter at 10th internode (mm) & $7.02 \pm 0.39$ & $7.15 \pm 0.40$ & ns \\
\hline Lateral cane diameter at 3rd internode (mm) & $5.70 \pm 0.22$ & $5.65 \pm 0.13$ & ns \\
\hline Total leaf area from primary canes $\left(\mathrm{m}^{2} /\right.$ vine $)$ & $10.97 \pm 0.21$ & $10.02 \pm 0.28$ & * \\
\hline Total leaf area from lateral shoots $\left(\mathrm{m}^{2} /\right.$ vine $)$ & $3.13 \pm 0.09$ & $3.40 \pm 0.07$ & * \\
\hline Total leaf area $\left(\mathrm{m}^{2} /\right.$ vine $)$ & $14.38 \pm 0.28$ & $13.16 \pm 0.37$ & * \\
\hline
\end{tabular}

${ }^{\text {a }}$ Significant differences (Signif.) are indicated: ${ }^{*}, p<0.05 ; \mathrm{ns}$, (not significant) according to $t$-tests.
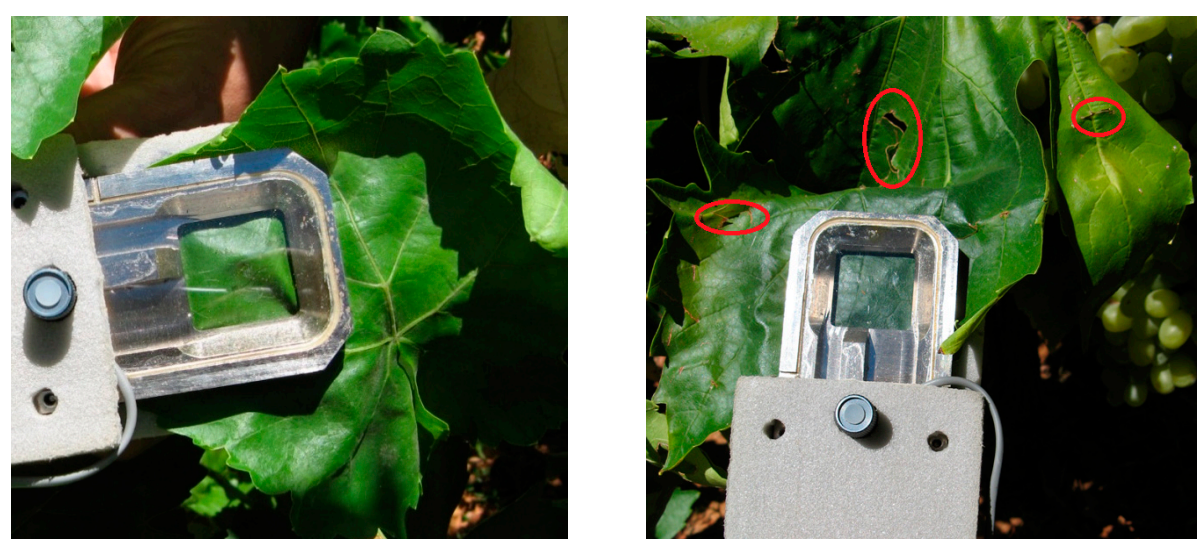

Figure 3. Undamaged leaves (left) and scarred basal leaves (right) of field-grown Thompson seedless vines. Picture was taken at harvest during the leaf gas exchange measurements; red ovals indicate the exact point where hailstones hit the leaf during the natural hail event that occurred four weeks after full bloom.

\subsection{Effect of Natural Hail on Leaf Gas Exchange}

Two days after natural hail (DOY 171), the leaf assimilation rate was not affected by natural hail in the basal or medial leaves (Figure 5A-C). Readings taken on lateral leaves essentially showed similar photosynthetic activity between treatments, although the lateral leaves from HD vines were developed after the hailstorm (Figure 5C). 

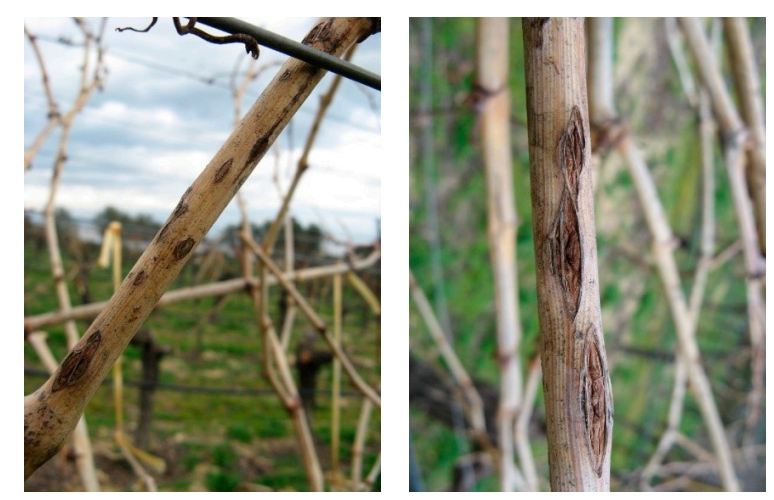

Figure 4. Morphology of canes of field-grown Thompson seedless vines during winter pruning with evident callus tissues after being damaged by natural hail the previous season.

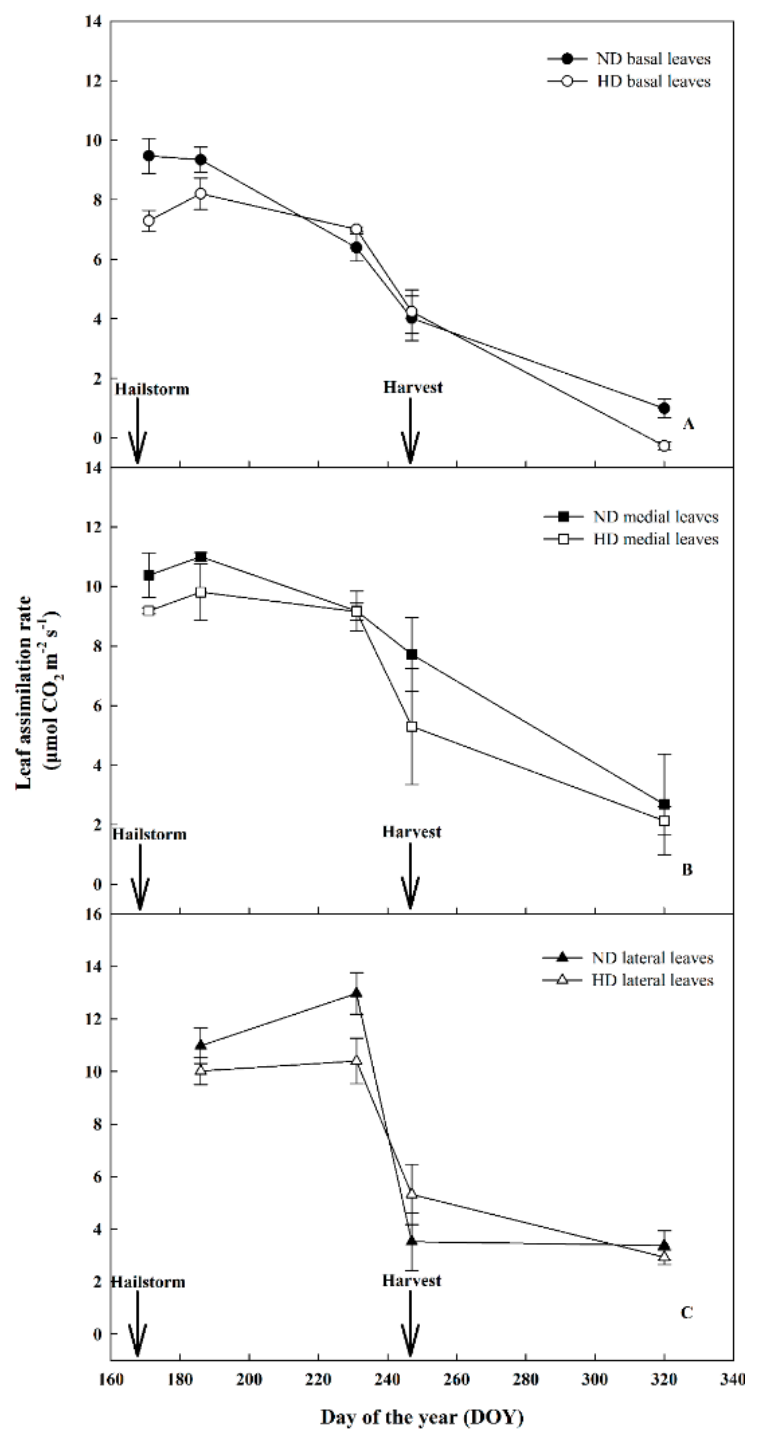

Figure 5. Seasonal changes in leaf assimilation rate (Pn) recorded in 2015 at different node positions along the main shoots: (A) in basal leaves, at the 3rd node; (B) medial leaves, at the 10th node; and the lateral shoots (C) (medial leaves, 3rd node) of non-hail-damaged (ND) and hail-damaged (HD) field-grown Thompson seedless vines. The hailstorm corresponded to day of the year (DOY) 169 in 2015, whereas harvest corresponded to DOY 248. Arrowheads indicate the time of hailstorm and harvest. Data are means $(n=5) \pm$ standard errors represented by bars. 
Even though no significant differences were recorded for E between ND and HD basal leaves (Figure 6A), the medial and lateral leaves from $\mathrm{HD}$ vines significantly increased $\mathrm{E}$, with a maximum of $67 \%$ and $37 \%$, respectively, during the first 20-25 days after the hailstorm (Figure $6 \mathrm{~B}, \mathrm{C}$ ). Sixty days after the hailstorm, these HD leaves showed $\mathrm{E}$ values similar to ND leaves up to values of approximately $3.0 \mathrm{mmol} \mathrm{H}_{2} \mathrm{O} \mathrm{m}^{-2} \mathrm{~s}^{-1}$ (Figure $6 \mathrm{~B}, \mathrm{C}$ ). The initial increase in transpiration of hail-injured leaves has also been documented in the literature for hail simulations [6], but in our case, it was more persistent. Perhaps due to a limited capacity of vine leaves to rapidly injure (e.g., by lignification at the edges of wounded leaf tissue) or to further abiotic stress (e.g., high-temperature stress), this abiotic stress situation was able to delay the recovery of evapotranspiration [26]. On the other hand, no significant differences of instantaneous $\mathrm{WUE}_{\mathrm{i}}$ were registered between treatments (Figure 7A-C).

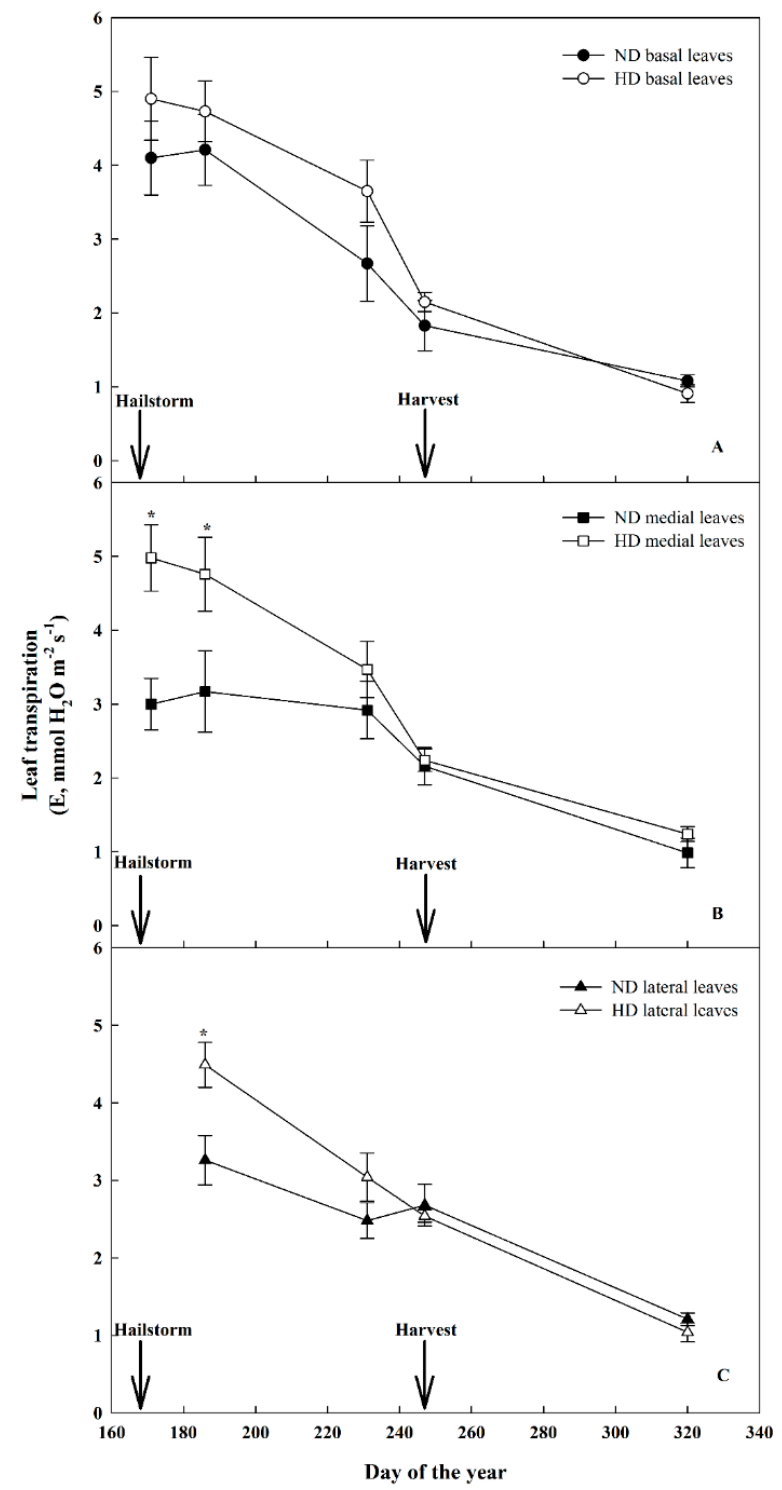

Figure 6. Seasonal changes in leaf transpiration rate (E) recorded in 2015 at different node positions along the main shoots: (A) in basal leaves, at the 3rd node; (B) medial leaves, at the 10th node; and the lateral shoots (C) (medial leaves, 3rd node) of non-hail-damaged (ND) and hail-damaged (HD) field-grown Thompson seedless vines. The hailstorm corresponded to day of the year (DOY) 169 in 2015, whereas harvest corresponded to DOY 248. Arrowheads indicate the time of the hailstorm and harvest. Data are means $(n=5) \pm$ standard errors represented by bars. Asterisks indicate significant differences according to $t$-test, $p<0.05$. 


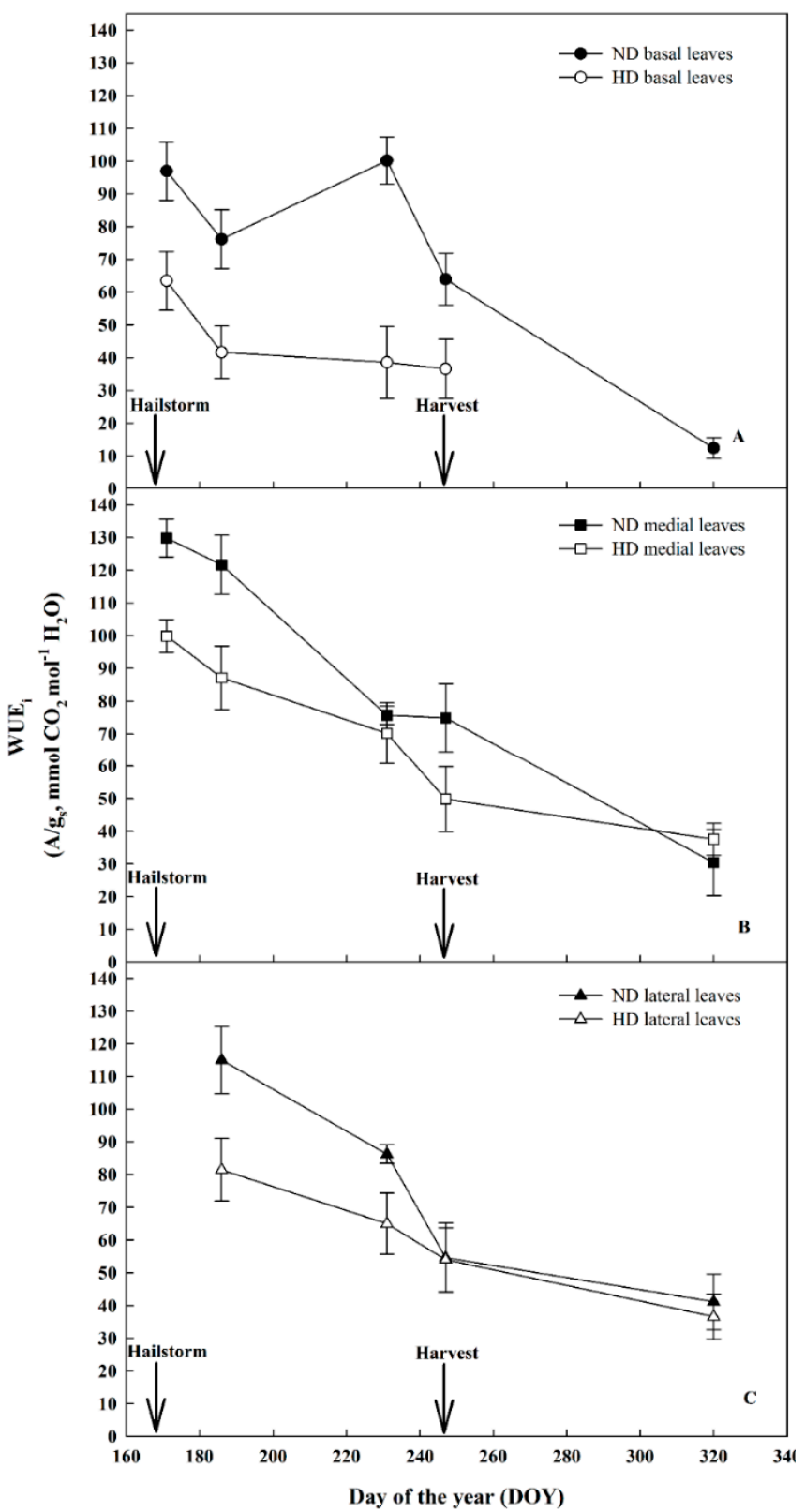

Figure 7. Seasonal changes in intrinsic water use efficiency $\left(W_{U} E_{i}\right)$ recorded in 2015 at different node positions along the main shoots: (A) in basal leaves, at the 3rd node; (B) medial leaves, at the 10th node; and the lateral shoots (C) (medial leaves, 3rd node) of non-hail-damaged (ND) and hail-damaged (HD) field-grown Thompson seedless vines. The hailstorm corresponded to day of the year (DOY) 169 in 2015, whereas harvest corresponded to DOY 248. Arrowheads indicate the time of the hailstorm and harvest. Data are means $(n=5) \pm$ standard errors represented by bars.

These results are in accordance with previous works on the effects of mechanical stress caused by, for example, hailstorms $[6,39,40]$ or an invasion of insect herbivory [41] on leaf gas exchange. As reported by Tartachnyk and Blanke [4] for mechanically hail-injured four-year-old apple trees (Malus domestica Borkh. cv. "Golden Delicious") and Aldea et al. [40] for soybean plants (Glycine max L., cv. Pioneer 93B15) damaged by Japanese beetles (Popillia japonica) and corn earworm caterpillars (Helicoverpa zea Bodie), the stress induced by hailstorms and insect herbivory, respectively, increased the transpiration but did not have a significant effect on the rate of net photosynthesis of damaged leaves. 


\subsection{Effect of Natural Hail on Productive Traits}

Starting from a uniform bunch number per vine, the yield, bunch weight, and berry weight were affected by natural hail (Table 2). At harvest, in HD vines, the yield per vine and bunch weight were significantly reduced by about $39 \%$ and $29 \%$, respectively, as compared with ND treatment. These reductions were attributable to a significantly lower number of undamaged berries per bunch (up to $44 \%$ less than ND), and consequently, bunch width and compactness were reduced in HD vines (Table 2).

Table 2. Yield components and bunch and berry characteristics (mean $\pm \mathrm{SE}, n=20$ ) at harvest in non-hail-damaged (ND) and hail-damaged (HD) field-grown Thompson seedless vines.

\begin{tabular}{cccc}
\hline Parameters & ND & HD & Signif. ${ }^{\text {a }}$ \\
\hline Bunches (number/vine) & $15.0 \pm 1.33$ & $13.2 \pm 2.65$ & $\mathrm{~ns}$ \\
Yield (kg/vine) & $13.10 \pm 0.33$ & $8.20 \pm 0.65$ & $*$ \\
Bunch weight $(\mathrm{g})$ & $874.10 \pm 107.61$ & $620.20 \pm 117.79$ & $*$ \\
Bunch length $(\mathrm{cm})$ & $21.8 \pm 1.6$ & $20.9 \pm 1.2$ & $\mathrm{~ns}$ \\
Bunch width $(\mathrm{cm})$ & $17.2 \pm 0.7$ & $14.6 \pm 0.8$ & $*$ \\
Bunch compactness index $\left(\mathrm{g} /(\mathrm{cm})^{2}\right)$ & $1.89 \pm 0.13$ & $1.40 \pm 0.19$ & $*$ \\
Undamaged berries per bunch $(\mathrm{n})$ & $167.0 \pm 3.2^{\mathrm{a}}$ & $93.0 \pm 3.1$ & $* *$ \\
Undamaged berry weight $(\mathrm{g})$ & $5.07 \pm 0.51$ & $5.19 \pm 0.61$ & $\mathrm{~ns}$ \\
Hail-damaged berries per bunch $(\mathrm{n})$ & $-{ }^{+}$ & $45.0 \pm 1.8$ & - \\
Hail-damaged berry fresh weight $(\mathrm{g})$ & - & $3.3 \pm 0.02$ & - \\
Undamaged berry length $(\mathrm{mm})$ & $27.11 \pm 0.44$ & $26.2 \pm 0.66$ & $\mathrm{~ns}$ \\
Undamaged berry diameter $(\mathrm{mm})$ & $17.88 \pm 0.31$ & $17.57 \pm 0.42$ & $\mathrm{~ns}$ \\
Force pedicel detachment $(\mathrm{N})$ & $1.6 \pm 0.22$ & $1.1 \pm 0.12$ & $\mathrm{~ns}$
\end{tabular}

a Significant differences (Signif.) are indicated: ${ }^{*}, p<0.05 ;{ }^{* *}, p<0.01 ; \mathrm{ns}$, (not significant) according to $t$-tests. ${ }^{+}$ Not detected.

Nevertheless, berry weight, width, diameter, and force pedicel detachment of undamaged berries from HD vines were unaffected by natural hail (Table 2), although the lack of response in terms of berry size on HD vines could simply be attributed to physiological berry growth compensation (fewer undamaged berries per bunch and a higher sink demand of undamaged berries compared with hail-damaged ones, on the same bunch, can lead to greater growth). It has to be noted that four weeks after full bloom (in concomitance with natural hail), this natural phenomenon was not effective enough to cause a severe source limitation, for example, on leaf gas exchange (Figure 5) during this stage of cell division, which in turn, could lead to a considerable reduction in final berry size. Indeed, Vasconcelos and Castagnoli [42] demonstrated that leaf removal, four weeks after bloom, had no impact on yield components, even though leaf removal can affect more or less the yield components in relation to the cultivar, severity, and time of treatment [43]. In our experimental conditions, natural hailstones were able to injure the epidermal cell of the berry and cause scarring (Figure 8), which probably led to suberification of the tissue, which in turn might have increased the weight loss of hail-damaged berries (Table 2). These hail-damaged berries should obviously be removed at harvest with appropriate clipping scissors in order to obtain marketable grapes-a process that increases the production cost of the crop.

\subsection{Effect of Natural Hail on Fruit Composition}

Natural hail occurring four weeks after full bloom increased TSS $\left(+1.0^{\circ} \mathrm{Bx}\right)$ at harvest (Table 3). The accumulation of sugar in the berries seemed to depend not only on the amount of yield (Table 2) but also the available active leaf area during the period between veraison and harvest. Indeed, during this period, HD vines presented a canopy composed of almost-young leaves, capable of fixing a sufficient amount of carbon, against ND vines composed only of old leaves for sugar accumulation in berries. This positive effect of lateral shoots on grape quality has already been demonstrated [44]. Several 
studies have shown that sugar accumulation is not affected [44,45] or even slightly increased [46-48] after reducing leaf area, similar to what happened in our study on HD vines (Table 1).
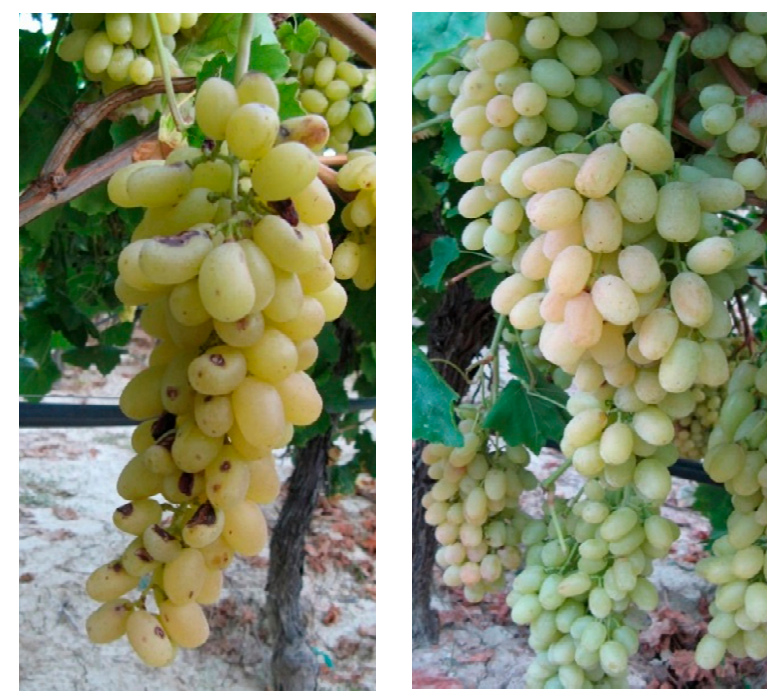

Figure 8. Cluster morphology of field-grown Thompson seedless HD (left) and ND (right) vines at harvest. Generally, the berries from HD vines presented unidirectional dorsal scars generated by natural hail that occurred four weeks after full bloom.

Table 3. Berry quality composition (mean $\pm \mathrm{SE}, n=5$ ) at harvest in non-hail-damaged (ND) and hail-damaged (HD) field-grown Thompson seedless vines.

\begin{tabular}{cccc}
\hline Parameters & ND & HD & Signif. $^{\text {a }}$ \\
\hline Total soluble solids (TSS, $\left.{ }^{\circ} \mathrm{Bx}\right)$ & $20.0 \pm 1.13$ & $21.0 \pm 0.85$ & $*$ \\
Total acidity (TA, $\%)$ & $0.39 \pm 0.01$ & $0.37 \pm 0.02$ & ns \\
Must pH & $4.27 \pm 0.08$ & $4.37 \pm 0.10$ & ns \\
Maturity index (TSS/TA) & $51.1 \pm 0.05$ & $57.0 \pm 0.19$ & ns \\
Total phenolics (mg/kg) & $1900.7 \pm 39.2$ & $975.5 \pm 15.4$ & $*$ \\
\hline
\end{tabular}

a Significant differences (Signif.) are indicated: ${ }^{*}, p<0.05$; ns, (not significant), $p>0.05$ according to $t$-tests.

Moreover, there were no significant differences in $\mathrm{TA}$, juice $\mathrm{pH}$, and maturity index among treatments (Table 3 ). These quality parameters at harvest were optimal and able to ensure a high-quality end-product, according to consumer preference [49]. The lack effect of natural hail on these qualitative parameters might be due to the minimal microclimate modifications around the cluster zone in our experimental conditions, since it is generally accepted that increasing cluster exposure to sunlight (perhaps indirectly caused by natural hail in our case, i.e., leaf gaps generated by hailstones) decreases juice acid content $[46,50]$.

However, natural hail affected the total phenolic levels at harvest with a fold change of $\sim 2$ between HD and ND berries (Table 3). Abiotic constraints are known to exert a negative effect on secondary metabolites, such as phenolic compounds [51]. Also, in our study, a competitive relationship between primary and secondary metabolites in berries was registered (Table 3), confirming other results reported previously [52,53]. In HD berries, the impact of natural hail might have inhibited phenolic biosynthesis and/or promoted phenolic degradation. Indeed, the biosynthesis and degradation of phenolic compounds seem to be under the control of enzymes that strongly reduce their activity under source limitations $[45,48]$. 
3.6. Effect of Natural Hail on Pruning Data, Vine Balance Indices, and Carbohydrate and Nitrogen Storage in Permanent Vine Organs and Shoot Fertility

The pruning weight did not differ between treatments (Table 4). Conversely, the yield-to-pruningweight ratio was affected by natural hail and decreased more than $37 \%$ on HD vines, while the leaf-to-fruit ratio increased by about $0.50 \mathrm{~m}^{2} \mathrm{~kg}^{-1}$ in HD vines as compared with ND ones (Table 4).

Table 4. Vine balance indices, cane wood reserves, and bud fertility (mean $\pm \mathrm{SE}, n=7$ ) in non-hail-damaged (ND) and hail-damaged (HD) Thompson seedless grapevines.

\begin{tabular}{|c|c|c|c|}
\hline Parameters & ND & HD & Signif. $^{a}$ \\
\hline Pruning weight $(\mathrm{kg} / \mathrm{vine})$ & $2.99 \pm 1.64$ & $3.03 \pm 0.13$ & ns \\
\hline Yield-to-pruning-weight ratio $(\mathrm{kg} / \mathrm{kg})$ & $4.38 \pm 0.04$ & $2.71 \pm 0.13$ & $* *$ \\
\hline Leaf-to-fruit ratio $\left(\mathrm{m}^{2} / \mathrm{kg}\right)$ & $1.10 \pm 0.15$ & $1.60 \pm 0.09$ & * \\
\hline Soluble solids of primary canes at 3rd internode (mg/g DW) & $167.88 \pm 16.98$ & $155.79 \pm 9.04$ & ns \\
\hline Starch of primary canes at 3rd internode $(\mathrm{mg} / \mathrm{g} \mathrm{DW})$ & $40.62 \pm 14.09$ & $50.82 \pm 11.58$ & ns \\
\hline Soluble solids of primary canes at 10 th internode (mg/g DW) & $147.06 \pm 3.63$ & $151.66 \pm 7.12$ & ns \\
\hline Starch of primary canes at 10th internode (mg/g DW) & $35.96 \pm 2.49$ & $35.58 \pm 7.61$ & ns \\
\hline Soluble solids of lateral canes at 3rd internode (mg/g DW) & $119.19 \pm 7.66$ & $146.36 \pm 17.95$ & ns \\
\hline Starch of canes of lateral canes at 3rd internode (mg/g DW) & $22.48 \pm 10.25$ & $39.67 \pm 5.47$ & ns \\
\hline$\ddagger$ Bud fertility index & $1.55 \pm 0.20$ & $2.08 \pm 0.40$ & $\mathrm{~ns}$ \\
\hline$\ddagger$ Blind buds/vine & $4.00 \pm 1.73$ & $5.67 \pm 2.40$ & ns \\
\hline
\end{tabular}

a Significant differences are indicated: ${ }^{*}, p<0.05 ;{ }^{* *}, p<0.01 ; \mathrm{ns}$, (not significant). $\ddagger$ Evaluated in spring 2016 and expressed as number of clusters per shoot per node position on the cane.

Analyses of the amount of total carbohydrates (total soluble sugars, reducing sugars, and sucrose) and insoluble (starch) carbohydrates at pruning (Figure 7) stored in the canes (primary and laterals) showed no differences between the two treatments, and consequently, no incidence to bud fertility or blind buds on HD vines was registered one year after the natural hail (Table 4). These results underline that the extent of this natural phenomenon was not large enough to cause mechanical damage to the shoots carrying the buds or latent bud differentiation interference, something that can be registered after a hailstorm [54] or during the year following defoliation, when lower vigor has been noted [55] as well as flower abscission [56] or lower bud fruitfulness. Moreover, lateral shoots were net exporters of carbohydrates, providing assimilates to support their own growth and sending the surplus to the main shoot, which contributed to berry ripening (Table 3).

\section{Conclusions}

The present study is the first attempt at quantifying natural hail effects on field-grown table grapes. Based on the results, the natural hailstorm caused an alteration in the source-sink relationship in Thompson seedless (V. vinifera L.) grapevines due to diminished leaf area induced by the hailstorm, which in turn led to lighter, less compact bunches and reduced the total phenolics of the berries. Moreover, this phenomenon implicates physiological and vegetative responses that can bring the vines to an acceptable maturity index without interfering with wood reserves or bud fertility in the following season.

Further investigation of these effects and in the presence of greater hail-damage impacts could be useful for better understanding the responses of grapevines under extreme abiotic conditions.

Author Contributions: Conceived, designed and supervised the experiment: D.G.P. Performed the analyses and collected the data: D.G.P., K.B., E.X., I.D., and. D.M. Wrote the manuscript: D.G.P. Reviewed the manuscript: D.G.P., K.B., and A.P. All authors have read and approved the manuscript.

Acknowledgments: We would like to thank the grapevine grower Georgios V. Petoumenos for hosting the vineyard trial, Evangelos Tyrlis for providing the meteorological data.

Conflicts of Interest: The authors declare no conflict of interest. 


\section{References}

1. Logothetis, B. The development of the vine and of viticulture in Greece based on archaeological findings in the area. In Epistimoniki Epetiris tis Geoponikis kai Dasologikis Scholis; University of Thessaloniki: Thessaloniki, Greece, 1970; Volume 13, pp. 167-249, (In Greek with English summary).

2. Staurakas, D.E. Ampelography, 2nd ed.; Ziti Press: Thessaloniki, Greece, 2015; pp. 588-594, ISBN 978-960-456-241-1.

3. Sioutas, M.; Meaden, G.; Webb, J. Hail frequency distribution and intensity in Northern Greece. Atmos. Res. 2007, 93, 526-533. [CrossRef]

4. Papagiannaki, K.; Lagouvardos, K.; Kotroni, V. A database of high-impact weather events in Greece: A descriptive impact analysis for the period 2001-2011. Nat. Hazards Earth Syst. Sci. 2013, 13, 727-736. [CrossRef]

5. Papagiannaki, K.; Lagouvardos, K.; Kotroni, V.; Papagiannakis, G. Agricultural losses related to frost events: Use of the $850 \mathrm{hPa}$ level temperature as an explanatory variable of the damage cost. Nat. Hazards Earth Syst. Sci. 2014, 14, 2375-2386. [CrossRef]

6. Tartachnyk, I.; Blanke, M.M. Effect of mechanically-hail simulated on photosynthesis, dark respiration and transpiration of apple leaves. Environ. Exp. Bot. 2002, 48, 169-175. [CrossRef]

7. Wells, L.D.; MacManus, P.S. Effects of simulated hail events and subsequent fungicide applications on cranberry fruit rot incidence and yield. Plant Dis. 2013, 97, 1207-1211. [CrossRef] [PubMed]

8. Jalali, A.H. Potato (Solanum tuberosum L.) yield response to simulated hail damage. Arch. Agron. Soil Sci. 2013, 59, 981-987. [CrossRef]

9. Miya, S.P.; Modi, A.T.; Mabhaudhi, T. Interactive effects of simulated hail damage and plant density on maize seed quality. Seed Sci. Technol. 2017, 45, 100-111. [CrossRef]

10. Anda, A.; Burucs, Z.; Lõke, Z.; Decsi, É.K. Effects of Hail on Evapotranspiration and Plant Temperature of Maize. J. Agron. Crop Sci. 2002, 188, 335-341. [CrossRef]

11. Robertson, A.E.; Munkwold, G.P.; Hurburg, C.R.; Ensley, S. Effects of Natural Hail Damage on Ear Rots, Mycotoxins, and Grain Quality Characteristics of Corn. Environ. Entomol. 2011, 103, 1193-1199. [CrossRef]

12. Yue, Y.; Zhou, L.; Zhu, A.-X.; Ye, X. Vulnerability of cotton subjected to hail damage. PLoS ONE 2019, 14, e0210787. [CrossRef] [PubMed]

13. Baldwin, J.G.; Bleasdale, G.E.; Cadman, R.S.; Keens, I.L. Comparison of trellises and pruning levels for Sultana vines in the Murray Valley. J. Exp. Agric. Anim. Husb. 1979, 19, 634-640. [CrossRef]

14. Williams, L.E.; Ayars, J.E. Water use of Thompson Seedless grapevines as affected by the application of gibberellic acid (GA3) and trunk girdling-Practices to increase berry size. Agric. For. Meteorol. 2005, 129, 85-94. [CrossRef]

15. Warusavitharana, A.J.; Tambe, T.B.; Kshirsagar, D.B. Effect of cytokinins and brassinosteroid with gibberellic acid on yield and quality of Thompson Seedless grapes. Acta Hortic. 2008, 785, 217-224. [CrossRef]

16. Abu-Zahra, T.R. Berry size of Thompson seedless as influenced by the application of Gibberellic acid and cane girdling. Pak. J. Bot. 2010, 42, 1755-1760.

17. Webb, L.; Whiting, J.; Watt, A.; Hill, T.; Wigg, F.; Dunn, G.; Needs, S.; Barlow, E.W.R. Managing grapevines through severe heat: A survey of growers after the 2009 summer heatwave in south-eastern. Aust. J. Wine Res. 2010, 21, 147-165. [CrossRef]

18. Flexas, J.; Bota, J.; Escalona, J.M.; Sampol, B.; Medrano, H. Effects of drought on photosynthesis in grapevines under field conditions: An evaluation of stomatal and mesophyll limitations. Funct. Plant Biol. 2002, 29, 461-471. [CrossRef]

19. Mosedale, J.R.; Wilson, R.J.; Maclean, I.M.D. Climate Change and Crop Exposure to Adverse Weather: Changes to Frost Risk and Grapevine Flowering Conditions. PLoS ONE 2015, 10. [CrossRef]

20. Morales, M.; Toro, G.; Riquelme, A.; Sellés, G.; Pinto, M.; Ferreyra, R. Effect of different rootstocks on photosynthesis and nutritional response of grapevines cultivar 'Sultanina' under flooding stress. Acta Hortic. 2014, 1045, 123-131. [CrossRef]

21. Takahashi, K.; Kuranaka, M.; Miyagawa, A. The effects of wind on grapevine growth: Windbreaks for vineyards. Bull. Shimane Agric. Exp. Stn. 1976, 14, 39-83.

22. Manja, K.; Aoun, M. The use of nets for tree fruit crops and their impact on the production: A review. Sci. Hortic. 2019, 246, 110-122. [CrossRef] 
23. Keller, M.; Romero, P.; Gohil, H.; Smithyman, R.P.; Riley, W.R.; Casassa, L.F.; Harbertson, J.F. Deficit irrigation alters grapevine growth, physiology, and fruit microclimate. Am. J. Enol. Vitic. 2016, 67, 426-435. [CrossRef]

24. Hendrickson, L.; Ball, M.C.; Wood, J.T.; Chow, W.S.; Furbank, R.T. Low temperature effects on photosynthesis and growth of grapevine. Plant Cell Environ. 2004, 27, 795-809. [CrossRef]

25. Petoumenou, G.D. Growth Rate, Morpho-Physiological and Ultrastructural Behaviour in Vitis Vinifera L. under Limited and Unlimited Conditions. Ph.D. Thesis, Università degli Studi di Perugia, Perugia, Italy, 2007.

26. Greer, D.H.; Weedon, M.M. The impact of high temperatures on Vitis vinifera cv. Semillon grapevine performance and berry ripening. Front. Plant Sci. 2013, 4, 1-9. [CrossRef]

27. Orduña, R. Climate change associated effects on grape and wine quality and production. Food Res. Int. 2010, 43, 1844-1855. [CrossRef]

28. Mori, K.; Goto-Yamamoto, N.; Kitayama, M.; Hashizume, K. Loss of anthocyanins in red-wine grape under high temperature. J. Exp. Bot. 2007, 58, 1935-1945. [CrossRef]

29. Sweetman, C.; Sadras, V.O.; Hancock, R.D.; Soole, K.L.; Ford, C.M. Metabolic effects of elevated temperature on organic acid degradation in ripening Vitis vinifera fruit. J. Exp. Bot. 2014, 65, 5975-5988. [CrossRef]

30. Lorentz, D.H.; Eichhorn, K.W.; Bleiholder, H.; Klose, R.; Meier, U.; Weber, E. Growth Stages of the Grapevine: Phenological growth stages of the grapevine (Vitis vinifera L. ssp. vinifera)-Codes and descriptions according to the extended BBCH scale. Aust. J. Grape Wine Res. 1995, 1, 100-103. [CrossRef]

31. Tello, J.; Ibáñez, J. Evaluation of indexes for the quantitative and objective estimation of grapevine bunch compactness. Vitis 2014, 53, 9-16.

32. Slinkard, K.; Singleton, V.L. Total Phenol Analysis: Automation and Comparison with Manual Methods. Am. J. Enol. Vitic. 1977, 28, 49-55.

33. Morris, D.L. Quantitative determination of carbohydrates with Dreywood's anthrone reagent. Science 1948, 107, 254-255. [CrossRef]

34. Loewus, F.A. Improvement in anthrone method for determination of carbohydrates. Anal. Chem. 1952, 24, 219. [CrossRef]

35. Fernandes, G.W.; Oki, Y.; Sales, N.M.; Quintini, A.V.; Freitas, C.; Caires, T.B. Hailstorm impact across plant taxa: Leaf fall in a mountain environment. Neotrop. Biol. Conserv. 2012, 7, 8-15.

36. Vescovo, L.; Gianelle, D.; Dalponte, M.; Miglietta, F.; Carotenuto, F.; Torresan, C. Hail defoliation assessment in corn (Zea mays L.) using airborne LiDAR. Field Crop. Res. 2016, 196, 426-437. [CrossRef]

37. Candolfi-Vasconcelos, M.C.; Koblet, W. Yield, fruit-quality, bud fertility and starch reserves of the wood as a function of leaf removal in Vitis vinifera-Evidence of compensation and stress recovering. Vitis 1990, 29, 199-221.

38. Caspari, H.W.; Lang, A.; Alspach, P. Effects of girdling and leaf removal on fruit set and vegetative growth in grape. Am. J. Enol. Vitic. 1998, 49, 359-366.

39. Tartachnyk, I.; Blanke, M.M. Temperature, evapotranspiration and primary photochemical responses of apple leaves to hail. J. Plant Physiol. 2008, 165, 1847-1852. [CrossRef]

40. Aldea, M.; Hamilton, J.G.; Resti, J.P.; Zangelr, A.R.; Byerenbaur, M.R.; Delucia, E.H. Indirect effects of insect herbivory on leaf gas exchange in soybean. Plant Cell Environ. 2005, 28, 402-411. [CrossRef]

41. Kerchev, P.I.; Fenton, B.; Foyer, C.H.; Hancock, R.D. Plant responses to insect herbivory: Interactions between photosynthesis, reactive oxygen species and hormonal signalling pathways. Plant Cell Environ. 2012, 35, 441-453. [CrossRef]

42. Vasconcelos, M.C.; Castagnoli, S. Leaf canopy structure and wine performance. Am. J. Enol. Vitic. 2000, 51, 390-396.

43. Tello, J.; Ibáñez, J. What we know about grapevine bunch compactness? A state-of-the-art review. Aust. J. Wine Res. 2018, 24, 6-23. [CrossRef]

44. Sabbatini, P.; Howell, G.S. Effects of early defoliation on yield, fruit composition, and harvest season cluster rot complex of grapevines. HortScience 2010, 45, 1804-1808. [CrossRef]

45. Pastore, C.; Zenoni, S.; Fasoli, M.; Pezzotti, M.; Tornielli, G.B.; Filippetti, I. Selective defoliation affects plant growth, fruit transcriptional ripening program and flavonoid metabolism in grapevine. BMC Plant Biol. 2013, 13, 30. [CrossRef]

46. Poni, S.; Casalini, L.; Bernizzoni, F.; Civardi, S.; Intrieri, C. Effects of early defoliation on shoot photosynthesis, yield components, and grape composition. Am J. Enol. Vitic. 2006, 57, 397-407. 
47. Poni, S.; Bernizzoni, F.; Civardi, S. The effect of early leaf removal on whole-canopy gas exchange and vine performance of Vitis vinifera L. "Sangiovese". Vitis 2008, 47, 1-6.

48. Pastore, C.; Zenoni, S.; Tornielli, G.B.; Allegro, G.; Dal Santo, S.; Valentini, G.; Intrieri, C.; Pezzotti, M.; Filippetti, I. Increasing the source/sink ratio in Vitis vinifera (cv. Sangiovese) induces extensive transcriptome reprogramming and modifies berry ripening. BMC Genomics 2011, 12, 631. [CrossRef]

49. Ranganna, S. Maturity Indeces and Quality Criteria. Grapes in Handbook of Analysis and Quality Control for Fruit and Vegetable Products, 2nd ed.; Tata McGraw-Hill Publishing Company Ltd.: New Delhi, India, 1986; p. 171, ISBN 007-451-851-8.

50. Poni, S.; Bernizzoni, F.; Civardi, S.; Libelli, N. Effects of pre-bloom leaf removal on growth of berry tissues and must composition in two red Vitis vinifera L. cultivars. Aust. J. Grape Wine Res. 2009, 15, 185-193. [CrossRef]

51. Mirás-Avalos, J.M.; Intrigliolo, D.S. Grape Composition under Abiotic Constrains: Water Stress and Salinity. Front. Plant Sci. 2017, 8, 851. [CrossRef]

52. Sadras, V.O.; Moran, M.A. Elevated temperature decouples anthocyanins and sugars in berries of Shiraz and Cabernet Franc. Aust. J. Grape Wine Res. 2012, 18, 115-122. [CrossRef]

53. Wu, B.H.; Niu, N.; Li, J.H.; Li, S.H. Leaf:fruit ratio affects the proteomic profile of grape berry skins. J. Am. Soc. Hortic. Sci. 2013, 138, 416-427. [CrossRef]

54. May, P. The value of an estimate of fruiting potential in the 'Sultana'. Vitis 1961, 3, 15-26.

55. Palliotti, A.; Gardi, T.; Berrios, J.G.; Civardi, S.; Poni, S. Early source limitation as a tool for yield control and wine quality improvement in a high-yielding red Vitis vinifera L. cultivar. Sci. Hortic. 2012, 145, 10-16. [CrossRef]

56. Lohitnavy, N.; Bastian, S.; Collins, C. Early leaf removal increases flower abscission in Vitis vinifera, Semillon. Vitis 2010, 49, 51-53.

(C) 2019 by the authors. Licensee MDPI, Basel, Switzerland. This article is an open access article distributed under the terms and conditions of the Creative Commons Attribution (CC BY) license (http://creativecommons.org/licenses/by/4.0/). 